\title{
PENERAPAN PEMBELAJARAN IPS DENGAN MEDIA ULAR TANGGA UNTUK MENINGKATKAN MINAT BELAJAR SISWA KELAS IV SDN KECAMATAN PRAMBON NGANJUK
}

\author{
Erwin Putera Permana, IImawati Fahmi Imron \\ erwinp@unpkediri.ac.id \\ Pendidikan Guru Sekolah Dasar \\ Fakultas Keguruan dan IImu Pendidikan \\ Universitas Nusantara PGRI Kediri
}

\begin{abstract}
From the observation results of research on class IV SDN Prambon Nganjuk, found some obstacles in learning the practice of IPS. Constraints of the teacher in the learning infrastructure is inadequate in elementary school and the teachers do not use the media to learn the lessons. Constraints of the students are students who have not been actively involved in learning social studies class. This study aims to describe the activities conducted teacher in learning activities using the media snake ladder, describe the students in learning activities using the media ladder snake, described the improvement of student learning through the media interest in snakes and ladders and describe the constraints of students through the medium of snakes and ladders in teaching social studies. In this research use classroom activities reseach. Subject and location of reseach is student of fourth class SDN Tanjungtani 3 Prambon Nganjuk, which consist of 27 students, 15 male students and 12 female students. In this reseach, reseacher using reseach instrument as data processing activities for teacher, student activities for students, students interest and interviews. Based on the results of learning activities using the media snakes and ladders to get a very good response from students. This can be evidenced teacher observations and student activities, teacher observations in cycle III reached $87.5 \%$ and the observation of the student activity a score $85.7 \%$. Besides the interest of the students show great interest in, this proved to achieve a score of 34.3. So snakes and leader media use to learning activities in class for study increase interest.
\end{abstract}

Keywords: snakes and ladders media, student interest in learning, teaching social studies

\begin{abstract}
Abstrak: Berdasarkan hasil observasi penelitian di kelas IV SDN Tanjungtani 3 Prambon Kabupaten Nganjuk, ditemukan beberapa kendala dalam praktek pembelajaran IPS. Kendala dari guru dalam pembelajaran yaitu (1) sarana dan prasarana SD yang kurang memadai, sehingga adanya keterbatasan sumber belajar dalam proses pembelajaran, (2) guru tidak menggunakan media pembelajaran, guru dalam pembelajaran hanya menjelaskan dan memberikan contoh berdasarkan buku paket dan mengisi LKS. Kendala dari siswa adalah siswa yang belum terlibat aktif dalam dalam pembelajaran IPS dikelas. Penelitian ini dilakukan bertujuan untuk mendeskripsikan aktivitas guru dalam kegiatan pembelajaran dengan menggunakan media ular tangga, mendeskripsikan siswa dalam kegiatan pembelajaran dengan menggunakan media ular tangga, mendeskripsikan peningkatan minat belajar siswa melalui media ular tangga dan mendeskripsikan kendala siswa melalui media ular tangga dalam pembelajaran IPS. Pada penelitian ini peneliti menggunakan penelitian tindakan kelas (PTK) dengan subjek dan lokasi penelitian adalah siswa kelas IV SDN Tanjungtani 3 Prambon Kabupaten Nganjuk yang terdiri dari 27 siswa, 15 siswa laki-laki dan 12 siswa perempuan. Pada penelitian ini peneliti menggunakan instrumen penelitian berupa lembar aktivitas guru, lembar aktivitas siswa, angket dan wawancara.
\end{abstract}

Kata kunci: media ular tangga, minat belajar siswa, pembelajaran IPS

\section{PENDAHULUAN}

Berdasarkan hasil observasi yang dilakukan oleh peneliti pada tanggal 11 dan 12 Maret 2015 pada pembelajaran IPS kelas IV semester II SDN Tanjungtani 3 Prambon, Kabupaten Nganjuk ditemukan beberapa kendala dalam praktek pembelajaran IPS antara lain (1) sarana dan prasarana SD yang kurang memadai, sehingga adanya keterbatasan sumber belajar dalam proses pembelajaran, (2) guru tidak menggunakan media pembelajaran, guru dalam pembelajaran hanya menjelaskan dan memberikan contoh berdasarkan buku paket dan mengisi LKS. 
Kendala lain juga ditemukan pada aktivitas siswa yaitu siswa yang belum terlibat secara aktif dalam pembelajaran IPS di kelas, terbukti hanya ada beberapa siswa yang memperhatikan guru saja sedangkan yang lainnya sibuk dengan kegiatannya sendiri, misalnya ada yang bercerita, tidur-tiduran di bangku dan bahkan ada yang sampai mengganggu teman yang lainnya. Aktivitas siswa semacam ini di duga menjadi indikator rendahnya minat siswa dalam mengikuti pelajaran IPS.

Didasarkan pada beberapa hal antara lain dengan menggunakan media di kelas, siswa akan lebih tertarik dan akan memusatkan perhatiaanya pada pelajaran IPS. Alasan lain adalah berkenaan dengan taraf berpikir siswa yang masih menggunakan cara berpikir kongkret dan berpikir secara sedernana. Didukung pula dengan teori Jean Piaget (dalam Danim, 2010:78) mengatakan bahwa anak pada usia 7-11 tahun masih menggunakan tahap operasional konkret (concrete operational stage), artinya pada fase ini anak dapat melakukan operasi dan penalaran logis, dan sepanjang penalaran dapat diaplikasikan pada contoh khusus atau konkret. Oleh karena itu, setiap guru dituntut untuk mempunyai kemampuan dalam penguasaan media. Guru yang terampil dalam menggunakan media diharapkan dapat meningkatkan minat dalam proses belajar mengajar di kelas sehingga siswa akan mudah memahami materi pembelajaran yang disampaikan guru.

Salah satu alternatif yang dapat digunakan sebagai upaya untuk meningkatkan minat belajar siswa kelas IV khususnya pada mata pelajaran IPS yaitu dengan menggunakan media ular tangga dalam proses pembelajaran. Alasan digunakannya media ular tangga karena sesuai dengan karakteristik siswa sekolah dasar yakni siswa umumnya lebih senang belajar dengan menggunakan media yang dapat dijadikan sebagai alat permainan. Banyak manfaat yang di dapat dari kegiatan bermain. Hal ini sesuai dengan pendapat Agus Mahendra (dalam Thobroni dan Fairuzul mumtaz, 2011:49) bahwa bermain dapat mengembangkan potensi anak dalam kehidupan kesehariannya meliputi faktor perkembangan fisikal, kognitif, emosional dan sosial.

Didukung pula dengan teori belajar J. Bruner (dalam Slameto, 2010:11) mengemukakan bahwa untuk meningkatkan proses belajar perlu lingkungan yang dinamakan "discovery learning environment", ialah lingkungan dimana siswa dapat melakukan eksplorasi, penemuan-penemuan baru yang belum dikenal atau yang mirip dengan yang sudah diketahui. Dalam lingkungan banyak hal yang dapat dipelajari siswa, yaitu a) enaktive, belajar yang harus didahului dengan bermacammacam keterampilan motorik b) ikonik, mengingat hal-hal yang penting dan c) simbolik, anak bisa menggunakan kata-kata, menggunakan formula. Ini berarti bahwa guru harus mengusahakan agar setiap siswa berpartisipasi aktif, minatnya perlu ditingkatkan, kemudian perlu bimbingan untuk mencapai tujuan tertentu.

Dalam pelaksanaan penelitian, peneliti terlebih dahulu menyampaikan informasi tentang aktivitas ekonomi yang berkaitan dengan sumber daya alam, kemudian peneliti membentuk siswa dalam beberapa kelompok, kemudian guru menggunakan media ular tangga dalam penyampaian materi, siswa mengamati yang dilakukan oleh peneliti kemudian peneliti meminta perwakilan kelompok siswa untuk mempraktikkan media tersebut sesuai bimbingan peneliti. Pembelajaran semacam itu, diharapkan siswa lebih aktif sehingga siswa tidak merasa jenuh atau bosan dengan materi yang disampaikan, siswa akan lebih antusias dan kecenderungan untuk lebih tertarik dan perhatian terhadap pelajaran IPS. Sehingga siswa lebih mudah untuk mengingat akan materi yang telah dipelajari dan tidak sekedar dalam angan-angan siswa.

Hal ini diperkuat dengan teori kerucut pengalaman Edgar Dale (dalam Sanjaya, 2010:165) yang menyebutkan bahwa pengalaman belajar yang diperoleh siswa dapat melalui proses perbuatan atau mengalami sendiri apa yang dipelajari, proses mengamati dan mendengarkan melalui media tertentu dan proses mendengarkan melalui bahasa. Semakin konkret siswa mempelajari bahan pengajaran, contohnya melalui pengalaman langsung, maka semakin banyaklah pengalaman yang diperoleh siswa. Sebaliknya semakin abstrak siswa memperoleh pengalaman, contohnya hanya mengandalkan bahasa verbal, maka semakin sedikit pengalaman yang diperoleh siswa. 
Adanya media ular tangga pada pembelajaran tersebut diharapkan siswa mengikuti penjelasan guru dalam setiap pembelajaran IPS, siswa mengikuti petunjuk dalam pembelajaran sesuai dengan yang dijelaskan oleh guru, siswa mencatat materi-materi atau penjelasan dari guru, siswa bertanya kepada guru jika tidak mengerti, siswa mencatat pelajaran dari teman bila siswa berhalangan hadir, siswa mengulas kembali pelajaran yang disampaikan guru dirumah, siswa selalu berusaha aktif selama kegiatan belajar, siswa tetap belajar walaupun tidak ada guru, siswa dapat menyelesaikan pertanyaan yang disajikan melalui materi yang diajarkan, siswa berdiskusi dengan anggota dengan anggota kelompoknya apabila mengalami kesulitan, siswa aktif memberikan pendapat, siswa aktif mencari jawaban, siswa aktif menulis laporan, siswa menyajikan hasil diskusi secara lengkap, siswa menyajikan hasil diskusi secara runtut, siswa menyajikan hasil diskusi dengan jelas, siswa menganalisis masalah dengan cermat, siswa mencari penyelesaian, siswa merumuskan jawaban, siswa mengerjakan dengan teliti, siswa mengerjakan sendiri, siswa menyelesaikan tepat waktu, siswa mengerjakan dengan cermat, siswa mencatat materi yang dijelaskan guru, siswa bertanya/menjawab pertanyaan, siswa menjawab dengan antusias, siswa menjawab dengan cepat, siswa menjawab dengan tepat/ benar, siswa menyimpulkan sendiri/bimbingan, siswa menyimpulkan seluruh pokok materi dan siswa mencatat rangkuman kesimpulan dari guru

\section{METODE PENELITIAN}

Penelitian ini merupakan penelitian tindakan kelas yang mengacu pada Arikunto (2008:3) bahwa penelitian tindakan kelas merupakan suatu pencermatan terhadap kegiatan belajar berupa sebuah tindakan, yang sengaja dimunculkan dan terjadi dalam sebuah kelas secara bersama. Subjek penelitian yaitu siswa kelas IV SDN Tanjungtani 3 Prambon Kabupaten Nganjuk yang terdiri dari jumlah 27 siswa, 15 siswa laki-laki dan 12 siswa perempuan.

Penelitian ini mengambil lokasi di SDN Tanjungtani 3 Prambon, Kabupaten Nganjuk yang beralamatkan desa Tanjungtani Kecamatan Prambon Kabupaten Nganjuk. Pelaksanaan penelitian tindakan kelas ini dilaksanakan sebanyak tiga siklus. Siklus pembelajaran dengan menggunakan media ular tangga dilakukan dalam waktu $3 \times$ pertemuan $(9 \times 35$ menit). Data yang akan dikumpulkan dalam penelitian ini adalah data deskriptif kuantitatif dan kualitatif dengan menggunakan Instrumen Penelitian adalah observasi guru, siswa, angket dan wawancara.

Dalam menganalisis data hasil observasi baik guru maupun siswa, peneliti menggunakan rumus:

(Aqib, 2009:41)

$$
P=\underline{\text { skor yang diperoleh }} \times 100 \%
$$

$$
\text { Skor maksimal }
$$

Untuk menghitung rata-rata keseluruhan jawaban dari angket yang telah terkumpul, dengan menggunakan rumus sebagai berikut:

\section{Rata-rata}

$$
\mathrm{M}=\frac{\sum f \mathrm{x}}{\mathrm{N}}
$$

Keterangan :

$$
\begin{array}{ll}
\mathrm{M} & =\text { Mean } \\
\sum_{N} \mathrm{fx} & =\text { Jumlah frekuensi nilai keseluruhan } \\
& =\text { Jumlah individu }
\end{array}
$$

\section{Indikator Keberhasilan Penelitian}

Penelitian ini dianggap berhasil jika:

1. Dalam kegiatan pembelajan aktivitas guru mencapai keberhasilan apabila keberhasilan mencapai $\geq 80 \%$

2. Aktivitas siswa dalam kegiatan pembelajaran mencapai keberhasilan apabila mencapai $\geq 80 \%$

3. Minat belajar siswa dalam kegiatan pembelajaran mencapai keberhasilan mencapai skala $\geq 33$ 


\section{HASIL DAN PEMBAHASAN PENELITIAN}

Penelitian ini dilakukan dalam tiga siklus, untuk setiap siklus dilakukan empat tahapan, yaitu: perencanaan, pelaksanaan, pengamatan dan refleksi. Peneliti menggunakan dua tahapan untuk menjabarkan hasil penelitian yaitu pengamatan dan refleksi.

Data perbandingan hasil penelitian siklus I, siklus II dan siklus III dapat dilihat pada tabel seperti berikut ini:

\begin{tabular}{|l|l|c|c|c|}
\hline \multicolumn{1}{|c|}{ No. } & \multicolumn{1}{|c|}{ Aspek } & Siklus 1 & Siklus 2 & Siklus 3 \\
\hline 1. & Persentase keberhasilan guru dalam mengajar & $73,6 \%$ & $79 \%$ & $87,5 \%$ \\
\hline 2. & $\begin{array}{l}\text { Persentase keberhasilan siswa dalam kegiatan } \\
\text { belajar mengajar }\end{array}$ & $64,2 \%$ & $69,6 \%$ & $85,7 \%$ \\
\hline 3. & Skor minat dalam angket & 30,5 & 32,07 & 34,3 \\
\hline
\end{tabular}

Dari tabel di atas menunjukkan bahwa adanya peningkatan antara persentase keberhasilan guru dalam mengajar, persentase keberhasilan siswa dalam kegiatan belajar mengajar dan skor minat dalam angket pada siklus I, siklus II dan siklus III. Hal ini sudah sesuai indikator keberhasilan dalam penelitian.

\section{SIMPULAN DAN SARAN Simpulan}

Berdasarkan hasil analisis dan pembahasan, dapat disimpulkan sebagai berikut. (1) Keberhasilan pada siklus I, II dan III sudah mengalami peningkatan dalam pembelajaran. (2) Aktivitas siswa pada siklus I, II dan III selama proses pembelajaran dengan menggunakan media ular tangga mengalami peningkatan. (3) untuk hasil minat siswa secara keseluruhan, dalam penggunaan media ular tangga pada siklus I, II dan siklus II mengalami peningkatan.

\section{Saran}

Berdasarkan kesimpulan di atas, maka saran yang dapat diambil sebagai berikut. (1) Guru hendaknya lebih kreatif dan inovatif dalam menggunakan media pembelajaran sehingga dapat meningkatkan minat belajar siswa. (2) Guru disarankan menggunakan media ular tangga dalam pembelajarannya karena mampu meningkatkan aktivitas guru dan siswa. (3) Guru disarankan menggunakan media yang menarik agar siswa dapat berantusias dalam pembelajaran IPS.

\section{DAFTAR PUSTAKA}

Aqib, Zainal. 2010. Penelitian Tindakan Kelas untuk guru SD, SLB dan TK. Bandung: Yrama widya. Arikunto, Suharsimi dkk. 2008. Penelitian tindakan kelas. Jakarta: PT.Bumi aksara 2010. Prosedur Penelitian: Suatu Pendekatan Praktik. Jakarta: PT Rineka Cipta.

Danim, Sudarwan. 2010. Psikologi pendidikan (Dalam perspektif baru). Bandung: Alfabeta

2010. Strategi pembelajaran berorientasi standar proses pendidikan. jakarta:

Prenada media group

Slameto. 2010. Belajar dan faktor-faktor yang mempengaruhi. Bandung: Rineka cipta

Thobroni, M dan fairuzul mumtaz, Nurul. 2011. Mendongkrak kecerdasan anak melalui bermain dan permainan. Jogjakarta: KATAHATI. 